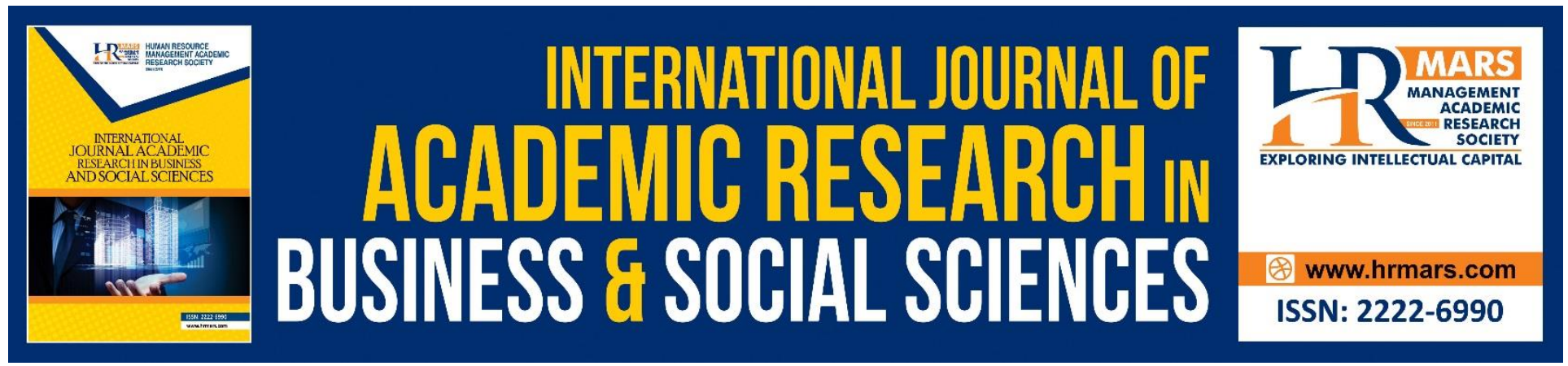

\title{
Democratization in Ethnocentric Society
}

\author{
Jazimin Zakaria, Sity Daud
}

To Link this Article: http://dx.doi.org/10.6007/IJARBSS/v8-i9/4688

DOI: $\quad 10.6007 /$ IJARBSS/v8-i9/4688

Received: 16 August 2018, Revised: 11 Sept 2018, Accepted: 29 Sept 2018

Published Online: 13 October 2018

In-Text Citation: (Zakaria \& Daud, 2018)

To Cite this Article: Zakaria, J., \& Daud, S. (2018). Democratization in Ethnocentric Society. International Journal of Academic Research in Business and Social Sciences, 8(9), 1164-1174.

\section{Copyright: (C) 2018 The Author(s)}

Published by Human Resource Management Academic Research Society (www.hrmars.com)

This article is published under the Creative Commons Attribution (CC BY 4.0) license. Anyone may reproduce, distribute, translate and create derivative works of this article (for both commercial and non-commercial purposes), subject to full attribution to the original publication and authors. The full terms of this license may be seen at: http://creativecommons.org/licences/by/4.0/legalcode

Vol. 8, No. 9, September 2018, Pg. 1164 - 1174

Full Terms \& Conditions of access and use can be found at http://hrmars.com/index.php/pages/detail/publication-ethics 


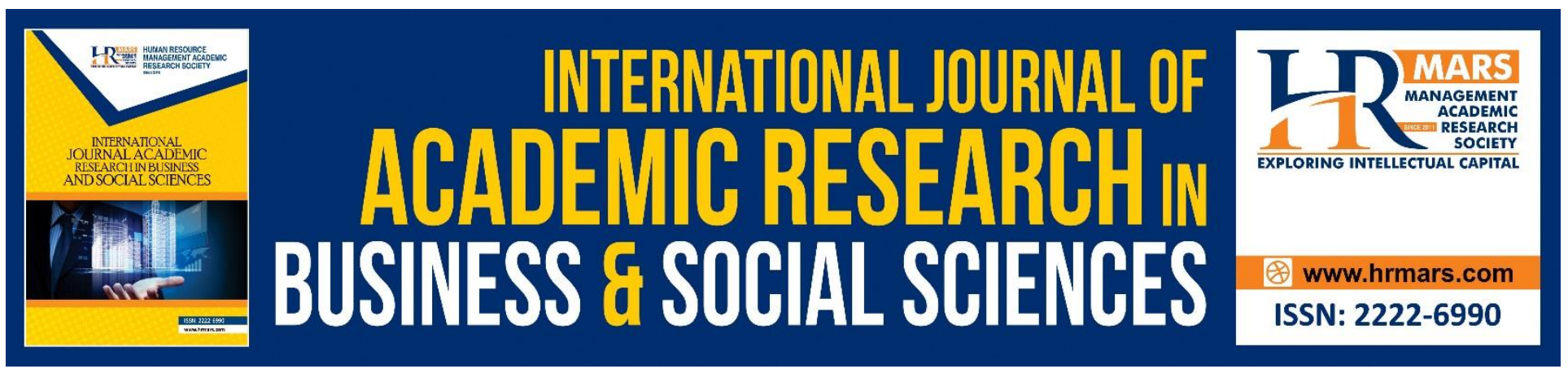

\title{
Democratization in Ethnocentric Society
}

\author{
Jazimin Zakaria, Sity Daud \\ Faculty of Administrative Science \& Policy Studies, MARA University of Technology \\ Faculty of Social Sciences and Humanity, Department of Political Sciences, National University of \\ Malaysia
}

\begin{abstract}
This paper discusses challenges for ethnically divided society in democratic countries. Generally, Malaysia fits as one. Since independence, Malaysia's political stability has frequently been tested by various ethnically-driven issues and challenges. Consequently, Malaysia came out with national integration policy in order to address those and integrate the ethnics. However, ethnocentrism along societal development has created tension among the ethnics and become obstacles in social integration. As a qualitative study, this paper looks at democratization in the ethnocentric Malaysian society from the inside, rather from the outside. It argues that despite the continuing efforts for democratization geared towards state development, socioeconomic disparities among ethnics are still prevalent and widespread. Among others, they have contributed to segregate economic control along social line rooted in preponderant social hierarchy among the ethnics in Malaysia.
\end{abstract}

Keywords: Democratization, Ethnocentrism, Disparities, Social Cohesion

\section{Introduction}

Malaysia inherited its former colonialist's system modelled after the democratic Western political structure. The impact of colonization leaves Malaysia with divided ethnic society fundamentally brought about by Britain's immigrant policy to cater for its industrial needs. Thus, Britain brought in millions of foreign labours from its other colonies like China and India into Malaysia resulting in drastic change to the local ethnic make-up, for which the Malays are the dominant race (Crouch, 1996). With the acceptance of the Chinese and Indian nationals as the citizens of an independent Malaysia, Malaysia has had to adopt a consociational democratic approach in order to accommodate the demands and needs of all its three major ethnics, and those of the other minorities. The consociational model came out as the Alliance political party (later Barisan National) managed to get massive support from the people in its quest to secure for independence through negotiation from Britain (Rabushka \& Shepsle, 1972). The Alliance consists of three main ethnic-based political parties i.e. United Malay National Organization (UMNO), Malaysia Chinese Association (MCA) and Malaysian India Congress (MIC). Each political party represents the three major ethnics respectively. Invariably, the establishment of ethnic-based political party was inevitable and, to some degree, relatively easy 
and less complicated to manage as it allows each to focus only on the interests and demands of a single ethnic.

Apparently, consociationalism has its flaws, like any other political models. Unable to fully integrate the ethnics, Malaysia has suffered a number of violent and fatal racial clashes. Following surprising results in the 1969 national election, the provocative procession of victory by the winning political parties such as Malaysian People's Movement Party (Gerakan) and Democratic Action Party known as DAP (whose memberships were dominantly Chinese) along the streets in the capital city of Kuala Lumpur had caused unrest especially among the Malays ethnic who were the dominant members of the rival party i.e. UMNO (Combers, 2011; Horowitz, 1998). It did not take long for UMNO members to set up their own procession to counter those of Gerakan and DAP. These parades eventually resulted in violent riots among the Malays and Chinese, and to some extent a number of Indians who largely took side with the Chinese. The election results that oversaw the transition of power in 1969 witnessed democracy in Malaysia had further emboldened ethnocentrism and with it, considerable impacts to the country's socio-economy and above all, social gap. Like many other multi-ethnic societies of the world, the complexity of a pluralist society appears to be one of the challenges to create political stability (Furnivall, 1886), for which this paper will deliberate upon.

\section{Challenges of Democratization}

Democratization of a pluralist society is intricate. The varieties of the ethnics, as one of the permanent legacies left behind colonialism, have led to a significant ethnic segregation that is remarkably primordial in nature (S.H.Ali, 2015; K.S. Jomo, 2007; Shamsul, 2014). The spread and adoption of the western-style democracy by many countries around the globe have subsequently resulted in the gradual democratization process of the political systems of those countries (Huntington,1991). However, this democratic transition has also produced skewed end-results i.e. different, often home-grown version of democracy that is applied by countries that are even and largely socialist in nature (Greenberg \& Page, 2011). Apparently, not all democratic transitions succeed. A number of countries only apply certain democratic principles such as election and equality but withhold a number of others like freedom of expression. The argument is that such is vital for the purpose of securing and maintaining political hegemony or to protect the interest of the few elites (Hilley, 2014; Parenti, 2002).

The ideals of a liberal western democracy time after time prove to be incompatible with maturing democracy in Asian countries, especially those in the Southeast Asia. Throughout the Cold War (19471991), most Asian countries found themselves at a crossroad between the need to accommodate a democratic political system and the demand to uphold their indigenous national characters. Malaysia is not an exception, thereby necessitating it to come up with its own version of democracy i.e. Asia Democracy (Khoo, 2002). For Mahathir (personal communication, February 16, 2017), democratization must not be absolute. In other words, there must always be a room for improvisations. At the initial stage, it should be only about the process to elect leaders among the people. It is only then that the wills of the members of the society gradually become more complex 
INTERNATIONAL JOURNAL OF ACADEMIC RESEARCH IN BUSINESS AND SOCIAL SCIENCES Vol. 8, No. 9, Sept. 2018, E-ISSN: 2222-6990 @ 2018 HRMARS

and multifaceted. As a result, in the name of human rights, they complicate democracy. More importantly, the protection of these rights has become the fundamental principle of democracy.

Seen from within the context of this study, democratization is indeed a challenge to a pluralist society. That is why, for Malaysia as a country that is composed of a variety of ethnics, in the face of democratization, national assimilation is definitely a daunting task. Things are not getting any easier if one is to put social contract into the equation. Obviously, the obligation to maintain such a contract that underlines sensitive elements for nation-building certainly does require a high degree of tolerance. Indeed, this can only be another challenge. Social contract, as it is enshrined and provided for in the constitution, outlines the privileges of the ethnic Malay in terms of status (Article 153), language (Article 152), religion (Article 3) and Malay Kings (Article 71). These are the subject matters that continue to be keenly debated by the other ethnics. This is even more prevalent among the new generations of Malaysian who consider those as irreconcilable with the ideals of human rights i.e. democratization. Besides, unlike the assimilation process in many other countries like in United States of America (USA), just to name an example, Malaysia does not apply the "melting pot" doctrine.

However, despite the orientation towards national integration serving as the base of Malaysia's social policy, it continues to be misunderstood as highly inclusive. It should be stressed herewith that although Malaysia does have an affirmative policy of its own, the rights of the other ethnics are carefully provided for in the constitution. Among others, the constitution can serve as a proof that Malaysia's social policy does not dismiss or deny the human rights of the other ethnics at the expense of the majority Malay ethnic (Faruqi, 2017). Speaking of affirmative policy, it turns out to be common as well in many other countries like India, Sri Lanka and even the USA itself.

The numbers of ethnic-based political party and civil movement that represent only a certain ethnic are also growing. Civil movements like those of Dong Jiao Zhong, PERKASA and HINDRAF have occasionally adopted a more aggressive approach when it comes to matters of ethnocentrism in nature. Often times, the demands for the equality of rights and the discontinuation of affirmative policy are interchangeably used or masked with the struggle for democracy. This, as a consequence, has complicated democratization to the extent that it might, against all odds, lead to or cause racial clashes.

Moreover, the issue of language also plays an instrumental role in uniting the people and the society. A single language can be just as the most important mechanism of national integration for a pluralist society. Yet, in the name of democracy, the provision for the right of freedom, and its application as a mechanism of unity must be upheld. According to Parekh (2015), in a pluralist society, language is vital in linking and amalgamating differences. Parekh argues that integration does not mean that an ethnic has to discard its identity. Nevertheless, uniting the differences certainly requires a single medium of language in order to make it work. Language is important in building a nation because of its capability to help a society form a sense of a common identity (Rahman, 2012). In Malaysia, despite the use of the Malay language as the official or national language, as stated by Article 152 of the 
INTERNATIONAL JOURNAL OF ACADEMIC RESEARCH IN BUSINESS AND SOCIAL SCIENCES

Vol. 8, No. 9, Sept. 2018, E-ISSN: 2222-6990 @ 2018 HRMARS

constitution, other languages remain free to continue to be used as a medium of interaction. This has never been a problem until the recent demand for use of languages other than Malay as a medium of instruction in public education system.

\section{Economic Disparities}

Democratization also poses a challenge to racial unity from the economic standpoint. Significant economic gap between the ethnics has inevitably created distinctive social classes between them. Generally, this circumstance is a major issue for all former colonised countries. By and large, the weakness of the political system proves to be an impediment for a fair and equitable implementation of the economic policy with the adoption of the free market has in parts aggravated the economic situation by influencing, in a negative way, the cost of living of the people. The elements of capitalism which is central to the free market economy have however deepened the segregation of the ethnics more so amongst those unintentionally marginalized or discriminated from national development policy (S.H. Ali, 2015).

In one way or the other, the monopoly of the economy has brought about prejudice among the ethnics (Horowitz 2014; Chua 2003). Chua (2003) asserts that the partnership of democracy and capitalism has compromised the otherwise harmonious life of the society by encouraging the creation of separate economic classes. Beyond doubt, differential status of life or class among the ethnics creates biased and prejudiced perception within the society. Obviously, it heightens up the possibility of a racial conflict. Additionally, the competition for material gains or satisfaction impedes racial unity more so, as it is perhaps always the case, when economic wealth and prosperity are the result of capitalism with a zero-sum game economy which, to some extent, does see oppression as an integral part of the free economy. Furthermore, the failure to ensure equitable distribution of the economy is equally responsible for the economic disparity. Mostly, it is the inefficient distribution of the economic resources that contribute to high cases of poverty (Gomez \& Jomo 1997; Syed Husin 2015).

In relation to the above, looking at the FORBES 2018 Malaysia Rich List, it shows that apparently only a single, minority ethnic dominates the economy and, with that, the evident huge gap of economic classes in Malaysia. The size of the wealth of those in the list is based on the values of shares, personal data and assets of their companies, among other things. Topping the list of the ten richest in Malaysia, as per the list, is Robert Kuok with a total of wealth valued at (US\$14.8 billion), followed respectively by Quek Leng Chan (US\$7.2 billion), Ananda Krishnan (US\$7.1 billion), Teh Hong Piow (US\$6 billion), Lee Shin Cheng (US\$5.6 billion), Lim Kok Thay (US\$4.7 billion), Chen Lip Keong (US\$3.3 billion), Koon Poh Keong \& Poh Ming (US\$3 billion), Lau Cho Kun (US\$2.6 billion) and finally Kuan Kam Hon (US\$2.5 billion). Undeniably, the glaring prevalence of the socio-economic classes has led to the rise of prejudice among the ethnics especially among and within those ethnics with inferior socio-economic status (Syed Husin 2015; Jomo \& Wee 2014; Chua 2003; Horowitz 2001). 
INTERNATIONAL JOURNAL OF ACADEMIC RESEARCH IN BUSINESS AND SOCIAL SCIENCES Vol. 8, No. 9, Sept. 2018, E-ISSN: 2222-6990 @ 2018 HRMARS

Table 1: Average Monthly Household Income According to Ethnic Groups in Malaysia, 1999-2016

\begin{tabular}{lllllllll} 
& 1999 & 2002 & 2004 & 2007 & 2009 & 2012 & 2014 & 2016 \\
\hline Malaysia & 2,472 & 3,011 & 3,249 & 3,686 & 4,025 & 5,000 & 6,141 & 6,958 \\
\hline Ethnic & & & & & & & & \\
Bumiputera & 1,984 & 2,376 & 2,711 & 3,156 & 3,624 & 4,457 & 5,548 & 6,267 \\
Chinese & 3,456 & 4,279 & 4,437 & 4,853 & 5,011 & 6,366 & 7,666 & 8,750 \\
Indian & 2,702 & 3,044 & 3,456 & 3,799 & 3,999 & 5,233 & 6,246 & 7,150 \\
Others & 1,371 & 2,165 & 2,312 & 3,561 & 3,640 & 3,843 & 6,011 & 4,951 \\
\hline
\end{tabular}

Source: Economic Planning Unit (EPU)

Table 1 highlights a number of facts. Firstly, it indicates that the economic gap between the ethnics is relatively closing up or growing smaller. However, for the Bumiputera (natives), they remain in the third rung of the economic class. This is not a good sign since they form the majority ethnic. Specifically, the Bumiputera commands only $23 \%$ in terms of the monthly household income with the Chinese at $32 \%$ and the Indian at $26 \%$. Secondly, Table 1 indicates that there is, for a two-year period, an increase of $5 \%$ of the monthly household income for the Bumiputera, $9 \%$ for the Chinese and $6 \%$ for the Indian. On a whole, such an increase for all ethnics is still considered as modest. Thirdly, there is a fluctuation of the monthly household income particularly between the year of 2009 and 2012 . Overall, there is a significant increase for all ethnics especially for the Indian. Such a growth, among other things, can be attributed to the national economic and development policy so designed to attract foreign investment to invest or open up their business in the country.

Moving on to the percentage of the incidence of poverty according to ethnic, it also shows a clearcut pattern. The Bumiputera has a $0.5 \%$ rate of poverty as opposed to $0.1 \%$ for the Chinese and Indian, as the following Table 2 shows.

Table 2: Incidence of Poverty According to Ethnic Groups in Malaysia, 1999-2016

\begin{tabular}{lllllllll} 
& 1999 & 2002 & 2004 & 2007 & 2009 & 2012 & 2014 & 2016 \\
\hline Malaysia & 8.5 & 6.0 & 5.7 & 3.6 & 3.8 & 1.7 & 0.6 & 0.4 \\
\hline Ethnic & & & & & & & & \\
Bumiputera & 12.3 & 9.0 & 8.3 & 5.1 & 5.3 & 2.2 & 0.8 & 0.5 \\
Chinese & 1.2 & 1.0 & 0.6 & 0.6 & 0.6 & 0.3 & 0.1 & 0.1 \\
Indian & 3.4 & 2.7 & 2.9 & 2.5 & 2.5 & 1.8 & 0.6 & 0.1 \\
Others & 25.5 & 8.5 & 6.9 & 9.8 & 6.7 & 1.5 & 0.9 & 1.5 \\
\hline
\end{tabular}

Source: Economic Planning Unit (EPU)

The national development policy definitely plays a role in influencing the aforementioned poverty incidence. As an instance, in 2013 the government introduced political reforms for students of Indian ethnic by launching a special education program for those Indian students with minimal pass qualification i.e. no credits in the national examination of Sijil Pelajaran Malaysia (SPM). Put in charge of this program, Polytechnic Malaysia developed a pre-diploma course that facilitated the enrolment 
of the students in question. Next, a special micro-credit financing scheme amounting to RM500 million for Indian entrepreneurs followed soon after. The government then allowed TEKUN (financing scheme for Bumiputera entrepreneurs) to extend its financing facility to include Indian ethnics who want to start businesses of their own. These reforms prove a point that the national development policy is inclusive and not strictly affirmative. Moreover, it also indicates that dynamism of the policy that makes it open to necessary changes and improvisations in order to ensure equitable distribution of national wealth. The government subsequently increased the intake quota for students of nonBumiputera ethnics into public universities from 30\% to 50\% (Muhammed Khalid 2014). True to form, the readiness and willingness on the part of the government to realize and protect the democratic rights of the people have had a positive impact on the issues related to the equality of rights across all ethnics. Hitherto, not only have all these helped in reducing the poverty rate among the minority ethnics, and in alleviating their economic status in the process, they have also justified the on-going drive to eliminate poverty and the affirmative elements of the national economic policy i.e. DEB. However, inefficient and disorderly implementation of the two have proven to be costly with the problem of the huge socio-economic gap between the ethnics remain unsolved.

On another note, the issue with education continues to be another challenge for democracy in Malaysia. Of particular significance is the existence of dual national education system i.e. national school and that of vernacular. The fact that matters is that the system of this nature has contributed to the growing polarization among the ethnics. While the pluralist nature of the Malaysian society has long posed a big challenge to the efforts towards achieving national integration, the continuance of the dual-national education policy complicates the already worsening national integration when in fact a single national education may just be the most effective mechanism for national integration and social unity (Heyneman, 2000).

The preceding differences among the ethnics can be overcome by the sense of camaraderie in in thoughts and social behaviours. Yet, looking at the current state of affairs Malaysia is in, it may not just be applicable. More than meets the eye, the existence of vernacular school is always seen as one of the stumbling blocks towards creating a common sense of nationhood, as proven otherwise by many countries who apply only a single education system. A single education system, Shamsul Amri (2014) adds, will be more than capable to unite the society by eliminating prejudice. True to form, an exclusive vernacular school that uses mother tongue language i.e. Chinese and Tamil as a medium of instruction does not bode well with a highly inclusive democracy in Malaysia. In the context of social integration, a pluralist society is clearly vulnerable to threats for not speaking a common language, among other things. On the contrary, by speaking identical language, the inter-ethnics relation in a pluralist society will only get to be better and stronger (Green et al, 2006). In addition to that, the lack of a common identity will also allow for unscrupulous politicians to play the racial cards to their own benefits (Heyneman, 2000). Over and beyond, only by having a single education can the people develop a high degree of tolerance and national unity (Putnam 2000). 
INTERNATIONAL JOURNAL OF ACADEMIC RESEARCH IN BUSINESS AND SOCIAL SCIENCES

Vol. 8, No. 9, Sept. 2018, E-ISSN: 2222-6990 @ 2018 HRMARS

\section{Bridging Ethnocentrism Society}

Democratization should be seen throughout social cohesion platform. Some countries with a pluralist society are consistently frustrated by their futile efforts to integrate the society and to create a common, national identity. Mostly, former colonies seem unable to completely rid themselves of ethnocentrism at all levels of the society. Conflicts that are motivated in part by ethnocentrism have made racism to be even worse, resulting in widespread oppression and discrimination. It is discomforting to see that the dominant majority ethnic is allegedly at the forefront of all those. Yet, racism is not exclusive to one group only i.e. majority ethnic. Chua (2003) notes that when democratization enters into a country, with liberalism, it will inexorably spread to all levels of the society. This, in turn, will create groups of capitalists who will afterward control the market. Chua adds that democratization also carries with it economic domination by a minority ethnic. This will only lead to dangerous racial conflicts. Up to some extent, the prevalence of distinct economic classes is also partly responsible to bring about imbalances between the ethnics for which those in the lower rungs of the economic class are more susceptible to be holding prejudiced perception against those above them.

Besides, Chua sees such an example in the Malaysian economy that is dominated by a minority ethnic in as much as it is the case with Thailand, Indonesia, Vietnam, Myanmar and the Philippines. Imbalances occurring in extraordinary circumstances can be attributed to the situation when the minority ethnics are not, when they are naturally and supposed to be, in the lower socio-economic class and discriminated against. Racism in USA, South Africa and a number of European countries can readily prove just that.

\section{Social Cohesion and Democracy}

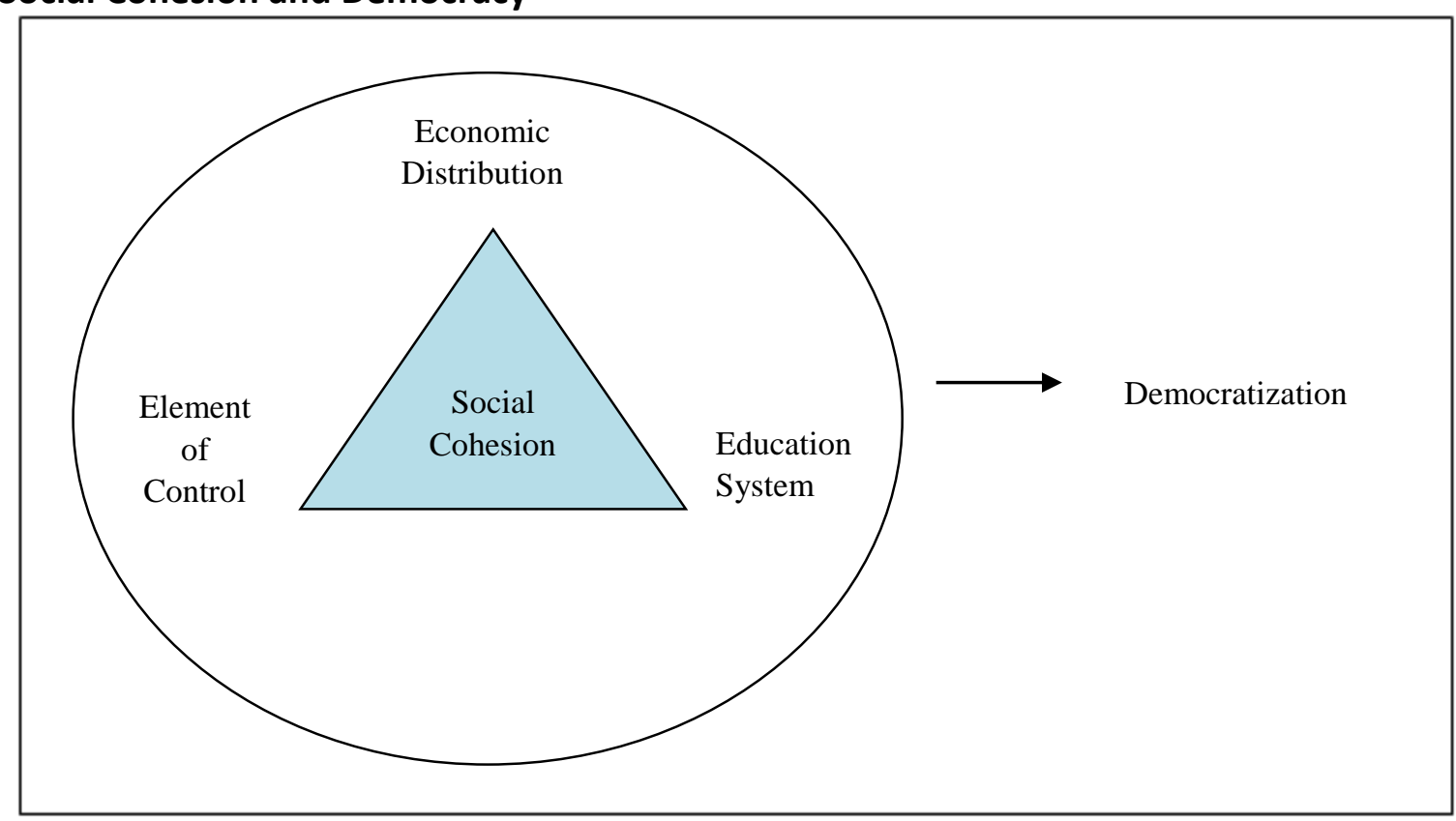

Diagram 1: Conceptual Framework 
In the context of democracy, social cohesion underlines suitable principles in guiding a pluralist society towards a full-fledged social integration and in so doing, eradicate ethnocentrism. The principles of social cohesion include quality, justice, civil society movement and the protection of human rights. These are, among others, the important values of social unity. They are also one of the reasons why social unity is not by nature domineering or overbearing. Instead, it is more of adaptation and circumstantial so much so that it is able to bring about unity in the society. The results of studies run by both Le Bon (1896) and Durkheim (1897) indicate that the feeling of being bound to a group or in short groupism does have positive effects. Besides, Fredkin (2004) points out that consensus is indeed a result of cohesion within a certain group. Clearly, the creation and maintenance of social cohesion is paramount for a democratically pluralist country in order to bind together all members of its society that come from different backgrounds. The persistent quest to find, establish and advance a common ground is definitely one of the useful ways to avoid and prevent conflict (Shamsul Amri 2014). Taken as a whole, unity is undoubtedly the right antidote against prolonged and protracted conflicts.

Moreover, only through social cohesion can the members of different ethnics come together and unite for common good. Easterly (2000) believes that social cohesion is the answer for all problems arising out of ethnic differences especially when it comes to issues regarding ethnic equality. In order to make it work, the political institutions must also carry out its vital role particularly in ensuring equitable distribution of resources in order to create, keep and improve the harmonious ethnic relations within a densely pluralist society (Easterly, 2006). However, controlling elements then must be of democratic nature as this will help to prevent any possible abuse in favour of political hegemony (Hilley 2015; Khoo 2002; Marzuki 2007). Control of the society has to be put in place in order to ensure that harmony is everlasting. Having said that, protecting and maintaining freedom of expression on the name of democracy does have its own issues and challenges that require careful and appropriate approach (Azizuddin 2010).

\section{Conclusion}

Since independence, ethnopolitics has ubiquitously served as the framework on which the foundation of Malaysia as a country is built upon. However, especially after 1969, its social unity has done just about enough in helping to maintain peace and political stability. Obviously, the country needs more than that. National building based on consensus has proven to be a success. Still, prevalent racial sentiments continue to linger. More often than not, a newer definition of democracy brought about by globalization has emerged as a key challenge to a pluralist society. As a consequence, the quest for democratization that comes with it tends to be misconstrued as an opportunity to strengthen ethnocentrism in the society. As for a country with a pluralist society such as Malaysia, it still has a lot to do before its democracy can fully mature. The fact is that, it still is undergoing a transitional period for democracy. While at it, Malaysia needs to guide the process with care so as to compromise the integrity of the framework that provides the foundation that builds the country. It is imperative that Malaysia seeks to preserve and protect its traditional elements as provided for in the constitution, the failure of which will definitely provide an impetus for racial conflict and political disaster. Liberal democracy in a pluralist society, built upon a strong 
INTERNATIONAL JOURNAL OF ACADEMIC RESEARCH IN BUSINESS AND SOCIAL SCIENCES

Vol. 8, No. 9, Sept. 2018, E-ISSN: 2222-6990 (C) 2018 HRMARS

ethnopolitics, is not necessarily a comforting association. On the other hand, it is almost always detrimental in nature. More than meets the eye, it is serving more as a constant threat to the country's political stability.

\section{Acknowledgement}

This research is part of PhD dissertation titled Democratization in Malaysia: Impact on National Integration.

\section{Corresponding Author}

Jazimin Zakaria

Faculty of Administrative Science \& Policy Studies, MARA University of Technology

Raub, 27600 Pahang, Malaysia

Email: rgbteam@yahoo.com.

\section{References}

Average Monthly Household Income According to Ethnic Groups in Malaysia, 1999-2016. Retrieved from http://www.epu.gov.my/ms.

Muzaffar, C. (2008). Hegemony: Justice; Peace. Selangor: Arah publication.

Chua, A. (2003). World on fire: How Exporting free market democracy breeds ethnic hatred and global instability. New York: Anchor Books.

Crouch, H. (1996). Government and society in Malaysia. Ithaca: Cornell University Press.

Deschouwer, K. (2005). Power Sharing New Challenges for Divided Societies (O'Flynn, I., \& Russell, D), The Unintended Consequences of Consociational Federalism: The Case of Belgium. London: Pluto Press.

Easterly, W. (2001). Can institutions resolve ethnic conflict? Economic Development and Cultural Change, 49 (4): 687-706.

Easterly, W. (2006). Centre for global development: social cohesion in direct masses.

Fish, M. S. \& Kroenig, M. (2006). Diversity conflict and democracy. Some evidence from uerasia and east europe. Democratization, 13(5): 828-842.

Friedkin, N., E. Social Cohesion Annual Review of Sociology. Vol. 30:409-425 (Volume publication date 11 August 2004) First published online as a Review in Advance on March 30, 2004 https://doi.org/10.1146/annurev.soc.30.012703.11062

Furnivall, J.S. (1948). Colonial policy and practice: A comparative study of Burma and Netherlands India. Cambridge: Cambridge University Press.

Green, A.; Preston, J.; Janmaat, J. (2006). Education equality and social cohesion: a comparative analysis. Springer.

Greenberg, E.S., \& Page, B.I. (2011). The Struggle for Democracy $10^{\text {th }}$ edition. United States of America: Pearson.

Heyneman, S. (2000). From the party state to multi-ethnic democracy: education and social cohesion Europe and Asia. Educational Evaluation Policy Analysis, vol. 22 no 173-191.

Horowitz, D. L. (2014). Ethnic Power Sharing: Three Big Problems. Journal of Democracy, 25 (2): 6-20. Horowitz, D. L. (2001). The Deadly Ethnic Riot. United States of America: University of California Press. 
INTERNATIONAL JOURNAL OF ACADEMIC RESEARCH IN BUSINESS AND SOCIAL SCIENCES

Vol. 8, No. 9, Sept. 2018, E-ISSN: 2222-6990 (C) 2018 HRMARS

Wealth of tycoons on 2018 Forbes Malaysia rich list soars. Retrieved from https://www.forbes.com/sites/forbespr.

Incidence of Poverty According to Ethnic Groups in Malaysia, 1999-2016. Retrieved from http://www.epu.gov.my/ms.

Huntington, S. P. (1991). The third wave: democratization in the late twentieth century. United States: University of Oklahoma Press.

Jomo, K. S. \& Gomez, E.T. (1997). Malaysia's Political Economy: Politics, patronage and profits. United Kingdom: Cambridge University Press.

Jomo, K. S. (2007). Malaysia's New Economic Policy and National Unity. Journal of Third World Quarterly, 11(4): 36-53.

Jomo, K. S. \& Wee Chong Hui. (2014). Malaysia@50: Economic development, distribution, disparities. Petaling Jaya: Strategic Information and Research Development Centre.

Khoo Boo Teik \& Francis Loh Kok Wah. (2002). Democracy in Malaysia, Discourses and Practices. United States: Prentice Hall.

Lijphart, A., Consociational Democracy. World Politics, Vol. 21, No. 2 (Jan., 1969), pp. 207-225 Published by: Cambridge University Press.

Lijphart, A., Crepaz, Markus M. L. (1991). Corporatism and Consensus Democracy in Eighteen Countries: Conceptual and Empirical Linkages. British Journal of Political Science, 21(2): 23546.

Mohamed, M. (2017, February 16). Personal interview.

Mohamad, M. (2007). Legal coercion, legal meaning and UMNO's legitimacy. In Edmund Terence Gomez E, T (eds.). Politics in Malaysia the Malay Dimension, pp. 24-49. London and New York: Routledge.

Khalid, M. A. (2014). The colour of inequality: ethnic, class, income and wealth in Malaysia. Petaling Jaya MPH Group Publishing sdn bhd.

Parekh, B. (2005). Unity and Diversity in Multicultural Societies. Lecture delivered at the International Institute for Labour Studies, Geneva. Available at $<$ www. ilo. org/public/english/bureau/inst/download/1parekh. pdf>. Introduction, 25.

Putnam, R. D. (2000). Bowling Alone: The Collapse and Revival of American Community. New York: Simon \& Schuster.

Rabushka, A \& Shepsle, K.A. (1972). Politics in plural societies: A theory of democratic instability. United States of America: Macmillan Publishing Company incorporated.

Baharuddin, S. A. \& Yusoff, A. Y. (2014). Perpaduan kesepaduan penyatupaduan: satu negara, satu akar, tiga konsep keramat. Institut kajian Etnik (KITA). Kuala Lumpur: Institut Terjemahan Buku Malaysia.

Ali, S. H. (2015). Ethnic relations in Malaysia Harmony \& Conflict. Kuala Lumpur: Strategic Information \& research Development Centre Malaysia. 